\title{
HEIDEGGER E O FIM DA METAFÍSICA
}

\section{ADRIELLE COSTA GOMES DE JESUS ${ }^{1}$}

RESUMO: Para Heidegger, com a chegada da era da metafísica acabada deve advir uma proposta de "outro começo", no qual assumiríamos uma relação mais originária com a nossa historicidade mediante um confronto meditativo com a tradição e com o presente. O que ele assume como tarefa de suas reflexões e como proposta de superação da metafísica, a partir da Kehre. Contudo, Heidegger admite que essa transição depende mais de determinadas disposições históricas do que de um empenho de superação. O que faria do pensador parte de um desvelamento histórico. Isso conduz a alguns interpretes a considerarem a sua filosofia, não só como uma tentativa de preparar um período pós-metafísico da história, mas também como parte de realização desse período da metafísica acabada. John Sallis considera Ser e tempo e os escritos da segunda fase como parte dessa realização. Nesse artigo, abordamos alguns aspectos essenciais da crítica sobre o fim da metafísica, bem como da proposta de superação desenvolvida por Heidegger tanto em Ser e tempo, quanto a partir da Kehre, para com base nelas questionar a tese de J. Sallis de que Ser e tempo é parte de uma realização do fim da metafísica.

PALAVRAS-CHAVE: Superação. Outro começo. Fim. Metafísica.

\begin{abstract}
According to Heidegger with the era of metaphysics accomplished should be offered a proposal of "another beginning", in which we would assume a more originary relation with our historicity through a meditative confrontation with the tradition and the present. He assumes it as a task of his reflections and as proposal of overcome metaphysics, since the Kehre. However, Heidegger admits this transition depends more of certain historical dispositions than of a commitment to overcome it. This would make the thinker part of a historical unconcealment. This leads some interpreters to consider his philosophy, not only as an attempt to prepare a post-metaphysical period of history, but also as part of an accomplishment of metaphysics. John Sallis considers Being and time and the writings of the second phase as part of this accomplishment. In this article, we discuss some essentials aspects of the criticism on the end of metaphysics, as well as the proposal of overcoming developed in Being and time and in the Kehre. On this basis, it will be questioned the Sallis's thesis which defends that Being and time is part of the end of metaphysics.
\end{abstract}

KEYWORDS: Overcoming. Another beginning. End. Metaphysics.

Podemos considerar Ser e tempo (2008) uma obra do fim da metafísica? Quais seriam as implicações de tal interpretação? Estaríamos com isso afirmando que é possível encontrar nessa obra uma leitura da era da técnica, bem como uma tentativa de levá-la a sua máxima

\footnotetext{
${ }^{1}$ Doutoranda em Filosofia pela Universidade Federal da Bahia (UFBA). E-mail: adriellecg@hotmail.com.
} 
realização? Ou esta interpretação contradiria os esforços do filósofo de questionar as insuficiências das determinações da história da metafísica?

À luz dos escritos sobre a técnica de Heidegger, John Sallis defende no livro Delimitations (1995) que Ser e tempo apresenta uma proposta de realização do "fim da metafísica”. E que desse modo, essa leitura não é exclusiva dos textos desenvolvidos a partir da Kehre, mas está subtendida no desenvolvimento de uma ontologia fundamental. Uma vez que encontramos nesta obra uma proposta de transgressão das determinações históricas da metafísica, o que seria equivalente a uma tentativa de realização de seu fim.

À primeira vista, essa defesa poderia parecer pertinente, se entendêssemos o "fim da metafísica" como sinônimo de sua proposta de superação. Contudo, se considerarmos as diferenças da proposta de superação da metafísica presentes nas duas fases da filosofia de Heidegger, perceberemos que nos escritos sobre a técnica a consumação do fim da metafísica ainda não é a superação de suas determinações. Mas, ao contrário, a sua máxima expressão.

Em Ser e tempo, por sua vez, não encontramos uma leitura do fim da metafísica como essa realização de sua extrema possibilidade. Mas uma defesa da necessidade de superar as suas determinações tradicionais, por ter desconsiderado e escamoteado a questão do ser.

Com efeito, apesar das diferenças, Heidegger mantém essa crítica sobre a desconsideração e o esquecimento da questão do ser em ambas as fases. Assim como nega a possibilidade de propor uma superação como uma ruptura com a história. Haja vista que somos determinados por uma historicidade e, desse modo, romper com a história da metafísica seria o mesmo que negar a nossa própria condição e a nossa proveniência. Assim, o reconhecimento de nossa historicidade faz parte do seu projeto de superação. Não obstante, o modo como Heidegger se propõe a fundar tal questão do ser nas duas fases apresenta diferenças marcantes, embora isso não se estabeleça como uma ruptura entre elas. Não só porque em Ser e tempo almeja alcançar a questão do sentido do ser por meio de uma analítica existencial e porque, posteriormente, abandona esse projeto em vista de uma virada em sua filosofia. Mas também porque, a partir dessa virada, a crítica de Heidegger não visa mais ao projeto inicial da modernidade, mas a sua fase tardia, chamada 'era da técnica'. E este é o período da história que Heidegger descreve como 'fim da metafísica'. Por isso, nos parece problemático considerar Ser e tempo uma realização do fim da metafísica.

Tendo isso em vista, procuramos problematizar essa interpretação nesse artigo. Optamos por fazer uma leitura não linear da filosofia de Heidegger. E por isso, iniciaremos a seguir apresentando alguns aspectos da segunda fase de sua filosofia que nos levam a 
perceber o modo como ele tece a sua crítica sobre essa era da metafísica acabada e o modo como ele propõe um "outro início" da história do pensamento ocidental, como superação de suas determinações. Posteriormente, retornamos a Ser e tempo, obra que marca a primeira fase de sua filosofia, para apresentar a sua proposta de destruição da metafísica, por meio da qual foi iniciada uma tentativa de superação. Bem como o seu conceito de ser-para-a-morte, o qual, supostamente, nos permitiria interpretar essa obra como realização do fim da metafísica. Por fim, explicitaremos e confrontaremos os argumentos de J. Sallis que sustentam essa leitura.

\section{Do primeiro ao outro início}

Se em outros escritos de Heidegger era possível perceber apenas de uma maneira tímida e esguia a sua ambição em oferecer reflexões que pudessem preparar uma nova época da história do pensamento Ocidental, em Contribuições à filosofia (2015) nos deparamos com afirmações mais contundentes sobre as suas pretensões. Neste livro, que é um conjunto de textos esboçados por Heidegger, originalmente apenas sobre a forma de manuscritos e que só foi publicado postumamente, percebemos que para ele, ao menos na segunda fase do seu pensamento, uma superação da metafísica só seria possível como inauguração de um outro início da história do pensamento ocidental. Embora neste livro ele afirme que Ser e tempo já ensaiava essa passagem do primeiro ao outro início, ao tratar do problema do sentido do ser como questão fundamental escamoteada pela pergunta pela entidade, que vigeu em toda a tradição metafísica, não é possível perceber indícios dessa leitura em Ser e tempo a não ser por meio de uma avaliação retrospectiva.

Em Contribuições à filosofia Heidegger torna explícita a sua defesa de que há uma necessidade de refletir sobre a possibilidade de um outro início para o pensamento ocidental. Para ele, tal reflexão precisa nascer de um confronto com o primeiro início da história, que se consumou como metafísica. Para que, a partir dele, se possa indagar sobre o problema da verdade como um acontecimento apropriador que se manteve latente em toda a tradição, mas que nem por isso deixou de ser determinante nas decisões históricas do pensamento ocidental. Contudo, o fato da verdade como acontecimento não ter sido questionada no primeiro início fez com que o pensamento ocidental tenha sido orientado pelas determinações do ente em sua 
totalidade, ou seja, pela assunção da entidade como fundamento, ao invés de ser orientada pela pergunta sobre o ser como acontecimento.

É com Platão que se inicia a história da metafísica. A tomada do conceito de Ideia como fundamento dos entes (i. é, como entidade dos entes) e a consequente divisão entre mundo inteligível e mundo sensível, configurou uma transformação essencial na determinação do ente em relação aos pensadores pré-socráticos. Antes, o modo de ser dos entes era pensado a partir da dinâmica de surgir e perecer da physis. E não havia um afastamento da questão, ou do pensamento, nem um primado deste em relação à physis. $\mathrm{O}$ modo de pensar sobre essa dinâmica de acontecimento partia da physis e se reconhecia como sua parte integrante. Da mesma maneira, não havia uma inclinação a pensar um fundamento para o seu modo de ser, embora, ao ver de Heidegger, a noção de physis já esboçasse uma determinação da entidade do ente, ainda que de um modo não ideal. Segundo ele, mesmo que a physis tivesse sido pensada como uma dinâmica de acontecimento, esses pensadores não questionaram a respeito da ambivalência presente nele. Essa ambivalência foi, então, pensada por Heidegger a partir da concepção de verdade como velamento e desvelamento. O importante a destacar aqui é que Platão é o marco decisivo para o nascimento da metafísica, na medida em que ele foi o primeiro pensador a questionar a origem, i.é., o fundamento para a totalidade do ente a partir de um âmbito ideal. Além disso, é o primeiro a atestar o primado do pensamento frente a physis, como aquilo que fornece acesso a Ideia. Ele desloca, assim, o pensamento do cerne da physis, para fundamentá-la na Ideia. Essa determinação orientou toda história do pensamento ocidental, a qual Heidegger considera como primeiro início. Até que assumiu a sua máxima expressão na era da técnica, na qual a vontade de poder passa a ser o novo princípio da metafísica, e esta, por sua vez, alcança o seu fim.

É preciso ter em vista que a crítica de Heidegger à metafísica vai amadurecendo ao longo dos seus escritos. Se nessa obra ele ensaia a possibilidade de pensar um recomeço não metafísico para a história do pensamento ocidental, o texto chamado $A$ superação da metafisica (2010), ainda que tenha começado a ser escrito na década de 30, apresenta uma leitura mais amadurecida sobre essa história. E passa a defender que é preciso pensar uma superação como reconhecimento do nosso incontornável modo de ser metafísico. De modo que a expectativa por um novo modo de desvelamento deve aceitá-lo como parte de nossa historicidade. Ele afirma: 
ou seja, da entidade, já se pensa a metafísica como um dar-se e acontecer que se apropria, de maneira ainda velada mas decisiva, do esquecimento do ser. [...] Passando, a metafísica é passado. O passado não exclui mas, ao contrário, inclui que somente agora a metafísica surge num domínio incondicional do próprio ente e, como tal, na configuração desprovida de verdade do real e dos objetos. Experienciada, porém, na perspectiva da aurora do começo, a metafísica é passado também no sentido de estar em seu acabamento. O acabamento dura mais do que a história da metafísica transcorrida até aqui. (HEIDEGGER, 2010, p. 61)

Nesse texto, Heidegger passa a defender uma superação não mais como uma saída da metafísica, mas como reconhecimento de sua incontornável determinação. Uma vez que o que está em jogo na era da técnica, período do acabamento da metafísica, é a própria recusa desse acontecimento. Isto é, passa a haver, a partir de Kant (seguido de Nietzsche, Husserl e da maior parte de filósofos contemporâneos), uma inclinação a eliminar a metafísica seja como uma disciplina inútil, seja como um modo de pensar que não satisfaz as condições para um conhecimento sólido sobre o mundo objetivo (Kant), ou ainda como algo que nega a própria vida e o devir, ao se pautar por um fundamento transcendente (Nietzsche). De modo que, na Modernidade, desde o seu início até o seu clímax, há uma exacerbação do ofuscamento da metafísica como um acontecimento de ser que determina todo o pensamento ocidental. A despedida da metafísica, consumada de fato na era da técnica, não é senão a expressão máxima dessa mesma metafísica iniciada com Platão, que se volta para a entidade como fundamento para tudo o que é. Ou seja, o auge da metafísica é o momento no qual não há mais espaço para qualquer questionamento sobre o ser. Para Heidegger, o que até então nenhum filósofo se deu conta é que é a própria desconsideração da questão do ser é o que faz de um pensamento filosófico algo metafísico. E mais do que isso, tal desconsideração não é um traço peculiar de alguns filósofos da tradição. Ela é um acontecimento que determina toda a história do pensamento ocidental, chamado por ele de "esquecimento do ser". Na era da metafísica acabada, tal determinação passa a viger como "esquecimento do esquecimento". Pois, deixa de haver qualquer indício do caráter de abertura desse acontecimento, já que não há mais, nem mesmo, o espaço para qualquer questionamento sobre a essencialidade de tudo que é.

Diante disso, nesse momento, é preciso para Heidegger pensar uma superação da metafísica que não se configure como uma passagem para um período não-metafísico da história. Já que esta ainda seria uma inclinação metafísica por excelência. E mais do que isso, seria um tipo de inclinação no qual o pensamento se veria incapaz de pensar a sua própria essência como acontecimento apropriador. Faz-se necessário, então, pensar uma superação 
que se reconheça como parte desse acontecimento incontornavelmente metafísico. E assim, abrir caminhos para pensar a nossa historicidade e o modo como ela se tece a partir de uma pertinência entre os seus diversos modos epocais de desvelar-se e o velamento de diversas outras possibilidades históricas.

Esse conceito de acontecimento apropriador (Ereignis), que aparece a partir da década de 30 na filosofia de Heidegger, é de suma importância para entender o aprofundamento da questão do ser ensaiado por ele ao longo de sua vida. Heidegger deixou a obra Ser e tempo inacabada porque se deu conta que o privilégio conferido ao Dasein $^{2}$ para o acesso à questão do ser acabou prolongando a herança metafísica que estabelecia o primado do homem como o lugar de fundação do ser. Mesmo que toda obra estivesse inclinada a superar tais determinações, os pressupostos de uma linguagem ainda impregnada de conotações da metafísica tradicional davam margem a uma recaída (HEIDEGGER, 1979, p, 156). Além disso, não foram raras as críticas de que Ser e tempo mantinha traços de uma filosofia transcendental. Diante dessa dificuldade, Heidegger decidiu manter essa obra inacabada, para pensar uma virada a partir de uma nova fase do seu pensamento, chamada Kehre, levada a termo a partir de 29. Doravante, o ser é tomado como o ponto de partida da questão e passa a possuir o primado frente ao Dasein. O ser é agora pensado como abertura, doação, desvelamento e velamento. E o Dasein, ou o homem, como o ente que corresponde ao seu apelo.

Aprofundando-se na questão do ser e desvencilhando-se gradativamente de uma linguagem ainda impregnada de pressupostos da metafísica, na década de 30 Heidegger passa a pensar o ser como um acontecimento apropriador. Com essa expressão, Heidegger apresenta uma nova abordagem à questão do ser, refletindo-o a partir de um acontecimento simultâneo de ser-tempo-espaço. Quando este acontecimento ocorre, há uma apropriação do homem (em alguns textos, como em Contribuições, ainda pensado como Dasein) como o lugar de fundação da verdade do ser. ${ }^{3}$ Ele também abandona o termo Dasein no pensamento tardio, limitando a referir-se a ele em passagens de reflexões retrospectivas sobre o percurso de sua filosofia, com o intuito de enfatizar que não há uma ruptura entre as fases de seu pensamento.

\footnotetext{
2 Optamos por não traduzir a palavra Dasein, com o intuito de manter uma uniformidade no conceito, diante da diversidade de traduções presente nas obras referidas nesse artigo.

${ }^{3}$ Em Contribuições à filosofia, Heidegger passa a utilizar a palavra Seyn no lugar de Sein. Com essa mudança na grafia da palavra ser ele pretende diferenciar a sua concepção de ser como acontecimento apropriador daquela estabelecida pela metafísica como entidade. Pretendendo, com isso, superar as suas recaídas na metafísica tradicional, tal como ocorre em Ser e tempo. Desse modo, encontramos em Contribuições duas concepções distintas, ainda que relacionadas, de ser: o ser enquanto acontecimento apropriador (Seyn) e o ser enquanto entidade (Sein).
} 
Mas, ao contrário, um movimento de aprofundamento da questão do ser, o qual o obrigou a repensar a linguagem que melhor expressaria tal questão. Contudo, em Contribuições à filosofia (escrita em 1935), que é o nosso foco neste momento, ele ainda mantém o termo Dasein para pensar essa relação entre ser e homem, doravante a partir desse acontecimento apropriador. Mas ele é pensado nesse momento de um modo ainda mais originário que em $\mathrm{Ser}$ e tempo, não só porque é o ser que se torna o ponto de partida de suas reflexões, mas também porque o Dasein é pensado em uma relação ainda mais próxima com ele.

Desse modo, percebemos que nesse momento Heidegger radicaliza a abordagem do Dasein. Se em Ser e tempo ele era pensado como o único ente capaz de ter compreensão de ser, aqui, essa caracterização não é mais suficiente. Passa a haver, doravante, um distanciamento originário do seu modo de ser do ente para que ele possa ser pensado em uma proximidade com o ser. Então, há nesse momento uma tripla relação de fundação: o ser funda o Dasein, o Dasein funda o ser do homem. E é o ser do homem que se entifica, consolidando uma de suas possibilidades históricas.

Mas essa questão sobre a proximidade entre o Dasein e o ser só pode encontrar o seu lugar em uma reflexão sobre o que ele chama de o "outro início" da história. Momento no qual a história da metafísica estaria superada. Desse modo, de acordo com Heidegger, não é possível conceber o Dasein a não ser como parte desse outro início que sucede ao período da metafísica acabada. Deparamo-nos aqui com uma ambiguidade: tanto em Contribuições à filosofia, quanto no texto A superação da metafísica, o filósofo nos adverte que ainda vivemos no período da metafísica acabada, e que assim, tal superação ainda não aconteceu. Mais do que isso, essa superação não pode ser pensada como algo que compete à escolha de um filósofo, mas deve advir de um novo acontecimento apropriador. Ou seja, é preciso que haja uma nova abertura histórica do ser para que essa superação seja de fato possível. Mas como é possível pensar na possibilidade histórica do Dasein e da verdade do ser sem que ela já esteja acontecendo? Ou seja, sem a permissibilidade de tal acontecimento apropriador? Heidegger diz em A questão da técnica (2010) que é possível manter uma relação livre com o nosso tempo e não sucumbir totalmente a tais determinações (HEIDEGGER, 2010, p.12). Como? Sendo capaz de pensá-lo em sua essência e com isso se dar conta de que tais determinações advêm de um acontecimento de ser. Mas precisamos admitir que isso não resolve a dificuldade de poder pensar elementos de um outro começo sem impor uma nova medida para ele, já que de fato ele ainda não aconteceu. E é a inclinação a tentar impor uma medida para o pensamento que Heidegger quer evitar. 
Contudo, aquém da pretensão de querer dar uma solução para essa dificuldade de pensar um modo de ser de um outro desvelamento epocal, sem que ele ainda tenha se dado, almejamos indicar que Heidegger acaba não encontrando outra saída - e, talvez, nem nos deixe outra saída - a não ser limitar-se a apontar que um possível novo modo de desvelamento epocal pudesse iniciar desse reconhecimento da verdade do ser como condição de nossa historicidade. Mas não seria possível saber quando, como e se ele de fato acontecerá. De modo que só nos restaria a expectativa de que um novo acontecimento pudesse surgir do pensamento sobre o ser. Dizer algo além disso acerca de um esperado período da metafísica superada, seria uma imposição de uma nova determinação a qual não compete ao homem conferir. E então teríamos, novamente, não mais uma superação, mas uma recaída em uma outra fundamentação metafísica, ainda circunscrita nos termos tradicionais. Com isso, não estamos afirmando que a possibilidade de uma nova época pensada por Heidegger pudesse ser destituída de qualquer medida. Mas que não compete ao homem constituí-la, pois ela advém de uma abertura originária, chamada por ele de acontecimento apropriador.

Mas a despeito dessa interpretação, precisamos deixar marcado que Heidegger não se decide sobre essa dificuldade e mantém a sua inclinação em preparar um outro início nessa ambiguidade há tanto presente em sua filosofia. E, talvez, ainda precisemos admitir que não podemos acusá-la de aporética, sem passar por cima e desvirtuar a circularidade que sempre prevaleceu como traço do seu discurso. Já em Ser e tempo ele dizia: "O decisivo não é sair do círculo mas entrar no círculo de modo mais adequado. [...] O círculo não deve ser rebaixado a um vitiosum, mesmo que apenas tolerado. Nele se esconde a possibilidade positiva do conhecimento mais originário. [...]"(HEIDEGGER, 2008, p, 214) Segundo Heidegger, a circularidade permite que possamos falar e questionar previamente acerca de algo sem termos um conhecimento consolidado sobre ele. A circularidade é a condição de toda e qualquer investigação e, mais do que isso, faz parte da constituição existencial do Dasein, tal como pensada em Ser e tempo. Como a leitura que estamos fazendo aqui assume a possibilidade de ler as duas fases do pensamento de Heidegger como um caminho de aprofundamento trilhado por ele, e não de uma ruptura, entendemos que existem aspectos dessa circularidade após a Kehre, embora não explicitamente e nem definida nesses termos. Pois, já não está em jogo a constituição existencial do Dasein como via de acesso à questão do ser. Por isso, preferimos pensá-la aqui como uma ambiguidade (ou ambivalência) sempre presente em seu pensamento.

Apesar de termos recusado caracterizar esse problema como uma aporia, não podemos livrar, com isso, Heidegger das questões ocasionadas pelas dificuldades presentes em sua 
filosofia. E precisamos reconhecer que pensar a possibilidade de um outro início é diferente de pensá-lo como reconhecimento do acontecimento apropriador. Mas, por outro lado, poderíamos questionar se, para Heidegger, um período que não trouxesse esse reconhecimento poderia ser considerado um outro início? Já que, para ele, esse outro início exige um salto do ente para a verdade do ser.

Tal salto é a condição para a transição do primeiro ao outro início: do ente ao ser, do pensar (representativo) ao tempo, como já ensaiava Ser e tempo. Nesse salto, o pensar deixa de possuir o primado para a determinação da entidade do ente e o ser passa a assumir esse lugar. O tempo, por sua vez, é revelado como essencialização da verdade. Segundo Heidegger, o primado do pensamento é o traço determinante do primeiro início. Pois, desde Platão, ele foi o fio condutor para todas as determinações históricas da entidade. Até que na Modernidade ele se configurou como único lugar de decisão e de constituição do ente, doravante como objetualidade. E mais do que isso, como razão assegurada de si e valendo-se da certeza como critério para o conhecimento seguro, passou a ser o fundamento de tudo o que é. Nietzsche tenta romper com esse primado ao inverter a oposição metafísica entre mundo sensível e mundo suprassensível e colocar a vida, os instintos, os impulsos no lugar do suprassensível. Mas, para Heidegger, ele não fora, com isso, capaz de transcender as limitações da metafísica e, ao invés disso, tornou-se a sua máxima expressão.

\footnotetext{
A filosofia de Nietzsche desprezou o pensamento em nome da "vida". Por não ter percebido, segundo a doutrina de Nietzsche, como é essencial para a "vida" tanto assegurar a consistência da re-presentação e planificação (apoderadoras) quanto a "intensificação" e a elevação. Estas foram consideradas apenas (psicologicamente) sob o aspecto da embriaguez, na perspectiva decisiva de serem o que confere o impulso próprio e renovado para o asseguramento da consistência das coisas e também o que justifica a intensificação. Pertence à vontade de poder o predomínio incondicional da razão calculadora e não a poeira e o caos de uma turva confusão vital. (HEIDEGGER, 2010, 70)
}

Com essa passagem, percebemos que, para Heidegger, Nietzsche não só mantém o primado do pensamento para a determinação do que o ente em sua totalidade é, como acaba por intensificar o domínio da razão ao fundá-la na atribuição da vida como vontade de poder. De modo que, para que uma superação da metafísica possa ser levada a termo é preciso que haja o salto da questão sobre o "ser do ente" para a questão sobre a verdade do ser.

Contudo, Heidegger admite a influência que Nietzsche exerceu sobre o seu pensamento, a ponto de considerar-se, também, como um niilista. Mas esclarece o tipo de niilismo que passa a assumir a partir de Nietzsche. Ele aponta Nietzsche como o ponto de 
partida para o futuro do pensamento ocidental. Pois, é o fim da metafísica prenunciado por ele que torna possível uma transição para a questão da verdade do ser. Esse fim é anunciado a partir da negação dos valores supremos estabelecidos pela tradição e da proposta de transvaloração, ao propor que o super-homem ocupasse o lugar do Deus metafísico. E por isso Nietzsche, apesar de ser considerado por Heidegger temporalmente o mais próximo de nós (por concernir à era da técnica), é o filósofo que se encontra mais distante da questão do ser. Heidegger, por sua vez, propõe outro tipo de inversão, e ao invés de estabelecer a vida como ponto de partida, atribui ao ser esse lugar. E é do ser, e não da negação dos valores supremos e de uma transvaloração, que advém o aspecto niilista de sua filosofia. Pois, como ele é destituído de uma fundamentação, Heidegger o considera um abismo, um nada, uma retirada ao velamento após doar-se a um tipo de desvelamento.

Essa assunção do ser como primado para as determinações históricas da entidade, é o que caracteriza o salto para um outro início para a história do pensamento ocidental. É por meio dele que se dá a passagem do que Heidegger chama de história da 'questão diretriz', isto é, a história que tomou como fio condutor a pergunta pela entidade, para a história da 'questão fundamental', que é esse outro início alcançado com a superação da metafísica e que leva em conta a verdade do ser como advinda de um acontecimento apropriador. Mas esse salto só é possível como e a partir de uma retomada do primeiro início. Essa retomada não se limita a uma revisão e correção historiográfica do passado, ao apontar aquilo que outros filósofos não se deram conta. Ela é uma retomada apropriadora, uma retomada de confrontação. Por meio dela, não só seria possível compreender que a verdade do ser sustentou o primeiro início, embora tenha permanecido inquestionada. Mas torná-la questão e mostrar o modo como ela determinou o primeiro início e como ela é a própria condição de sua historicidade, é o que caracteriza a tentativa de realizar o salto para o outro início. Esse retorno ao passado é assumido, assim, como um empenho para compreender a nossa condição atual e para preparar o nosso futuro.

\section{II}

\section{A destruição da metafísica}

Como Heidegger insiste em esclarecer, não só em Contribuições à filosofia, como também em vários outros escritos, essa tentativa de superação por meio de um retorno à história não é exclusividade de um pensamento desenvolvido a partir da Kehre. Ser e tempo 
também fora movido por esse empenho de superação da metafísica. E essa tentativa também foi orientada por um retorno aos pressupostos históricos dessa tradição. Mas esse retorno foi levado a termo como uma 'destruição' da metafísica.

Com essa expressão, Heidegger não pretende deitar por terra toda história da filosofia e defender que ela foi construída em cima de um erro. Ele afirma que ela tem um papel positivo de circunscrever os limites da tradição. Em vista disso, com o termo destruição (Destruktion) apresentado em Ser e tempo, ele nos propõe um esforço para desconstruir os pressupostos da metafísica para, assim, tornar manifesto a questão originária que se manteve latente, desde o início, em suas entrelinhas, porém esquecida, a saber: a questão do sentido do ser. Nesse sentido, a destruição da metafísica vem acompanhada de uma reconstrução, a partir da qual a questão do ser poderá ser revelada de um modo originário. Contudo, o filósofo nos alerta que essa questão não se limita a resolver um problema do passado, mas propõe uma crítica à nossa condição atual.

Qual seria a dificuldade que o esquecimento da questão do ser trouxe para o período contemporâneo? Segundo o filósofo, ela consumou uma compreensão simplesmente dada de nosso modo de ser e do mundo ao qual estamos concernidos (HEIDEGGER, 2008, p 563, N8). ${ }^{4}$ Essa compreensão se configurou na Modernidade pelo correlato sujeito-objeto, estabelecido pela filosofia da subjetividade inaugurada com Descartes. Contudo, Heidegger não atribui a responsabilidade unicamente ao período moderno por escamotear uma compreensão originária de nossa condição. Já na epígrafe de Ser e tempo ele aponta tal responsabilidade às escolhas históricas tomadas desde o início da tradição metafísica com Platão. Que apresentaria pela primeira vez a grande dificuldade para a questão do ser, que é a inclinação a escondê-lo em uma evidência aparente do fundamento do ente (no caso deste, a Ideia). Essa pressuposição foi assumida ao longo da tradição até cair no esquecimento, ao ponto de acusar quem ousasse levantar essa questão de cometer um erro metodológico (HEIDEGGER, 2008, p. 37).

Alguns críticos afirmam que já em Ser e tempo o intuito de Heidegger é pensar um recomeço não-metafísico para a história da filosofia (VALLEGA, 1995, p. XIV). Embora, nesse período, ele ainda não tenha chegado à conclusão que a filosofia tem caminhado para o seu fim, a proposta de uma destruição da questão fundamental da filosofia, e sua concomitante reconstrução, parece apontar para um recomeço no qual a filosofia é capaz de

\footnotetext{
${ }^{4}$ Ser simplesmente dado (Vorhandenheit) diz respeito ao modo de ser de uma coisa isolada do contexto referencial do mundo.
} 
reconhecer a questão que se manteve velada e esquecida durante toda a história da metafísica, que é a questão do sentido do ser.

Como já abordamos anteriormente, ao fazer uma avaliação retrospectiva dos caminhos iniciais do seu pensamento, em Contribuições à filosofia Heidegger aponta para uma tentativa de um recomeço não-metafísico para a história do pensamento ocidental em Ser e tempo. Contudo, o que ele não deixa claro, e do mesmo modo, o que ele não havia se dado conta nessa obra, é que nesse recomeço a virada do pensamento sobre o ente para o pensamento sobre o ser não pode mais se reconhecer como filosofia. Já que ela tem se transformado em ciência e técnica. Em Ser e tempo e em preleções próximas a esse período, como em Introdução à filosofia (2008) de 1929, ele não só já havia reconhecido a transformação da filosofia em ciência, como também, em certa medida, assumiu a sua ontologia como "ciência originária".

Porém, ele ainda não havia percebido que essa transformação já resguardava um desvelamento de um novo modo de ser, inaugurado como "Era da técnica". Nesse período, que nós podemos denominar de Modernidade tardia e no qual ainda estamos situados, a filosofia alcança o seu fim ao diluir-se na institucionalização do pensamento técnico. Isso não quer dizer que hoje não haja mais filosofia. Mas que ela tem se transformado, cada vez mais, em disciplinas e em conhecimentos cada vez mais específicos de ética, estética, epistemologia, metafísica... e estes são fundamentados de um modo separado uns dos outros. Nessa institucionalização, até a ontologia, que é pensada por Heidegger como ciência originária, isto é, como condição para qualquer investigação, passa a ser assumida como algo que compete a uma especialidade.

Assim, se a reflexão sobre essa 'questão fundamental' não é mais possível como filosofia, seria preciso, doravante, encontrar um novo lugar para ela. Por isso, a partir da Kehre Heidegger deixa de atribuir ao seu pensamento o título de ciência originária, e ao mesmo tempo o termo ontologia fundamental deixa de ser utilizado. Até que, sobretudo nos seus últimos escritos, ele passa a considerar a sua questão do ser como um pensamento meditativo.

O que é importante ressaltar aqui é que desde Ser e tempo percebe-se uma preparação para uma mudança na história do pensamento ocidental, embora ela não tenha sido pensada nos mesmos termos do período da Kehre e não seja anunciada de um modo tão explícito. Já que esta obra é apresentada como uma crítica e uma proposta de superação da tradição 
metafísica e não como uma tentativa de preparar um novo início para a história do pensamento ocidental.

III

\section{A finitude}

Essa possibilidade de já encontrar em Ser e tempo indícios que apontam para uma proposta latente de uma "virada epocal" nos conduz a uma outra questão: a despeito das diferenças entre as fases do pensamento de Heidegger, podemos considerar Ser e tempo uma obra do fim da metafísica? Para responder a essa questão, precisamos fazer algumas considerações sobre o que entendemos por fim e finitude, a partir das reflexões feitas por Heidegger no primeiro capítulo da segunda seção de Ser e tempo. Para então confrontá-la, no próximo item, com o argumento sustentado por John Sallis no livro Delimitations, como defesa dessa possibilidade.

Primeiramente, é preciso esclarecer a que dificuldade Heidegger pretende responder ao refletir sobre a nossa finitude. A tradição fillosófica, desde Platão, pensou os seus fundamentos como eternos e absolutos. A sua origem fora atribuída ao reino do suprassensível, que excedia às nossas limitações mundanas, imperfeitas e mortais. Ideia, substância, Deus, razão, são alguns dos modos pelos quais foram denominados os fundamentos atemporais e absolutos para tudo o que é. Ou seja, nos termos de Heidegger, foram alguns dos modos nos quais a entificação do ser foi determinada.

Segundo Dastur, essa tradição estabeleceu esses fundamentos em função da morte. Pois, a filosofia não ignorou o caráter mortal do ser humano. Contudo, ela não foi capaz de reconhecer a morte como uma determinação de nosso modo de ser. Ou seja, ela nunca fora assumida como um limite intransponível e como condição de nossas possibilidades de ser-nomundo. Mas sempre houve, ao contrário, uma inclinação a superá-la, ao tentar alcançar a eternidade. Mesmo Nietzsche, que anuncia a sua filosofia como antimetafísica, mantém esse legado ao valorizar a vida sem estabelecer uma relação com a sua finitude (DASTUR, 2008, 13 E 14). Isso não quer dizer que a tradição tenha desconsiderado o fato da morte, mas que ela tem um lugar negativo, sendo recusada a partir de um esforço para vencê-la, seja através da eternidade e do absoluto, seja na supervalorização da vida em detrimento da morte. 


\begin{abstract}
promessa de salvação pessoal; da ciência, que estabelece a validez de uma verdade independente dos mortais que a pensam, e mais geral do conjunto da cultura humana, posto que esta se baseia essencialmente na transmissibilidade dos conhecimentos e das técnicas que constituem o tesouro perdurável de uma comunidade de seres vivos que se estendem ao longo de várias gerações.[...] De modo que a melhor maneira de anestesiar o terror que nos inspira ao pensamento de nossa própria mortalidade é apelar ao que há em nós de impessoal e insensível, a razão universal e «eterna». (DASTUR, 2008, p. 21, tradução nossa).
\end{abstract}

Heidegger rompe com todo esse apelo ao absoluto preconizado pela história, seja como eternização da alma, como universalização e absolutização da razão, seja como eternização do devir. Doravante, o tempo passa a ser pensado como o que constitui o horizonte de sentido de ser. Recusando, com isso, a oposição nietzschiana entre ser e devir e a equivalência tradicional entre ser e absoluto/eternidade. "Ser" e "tempo" são, doravante, pensados de um modo copertinente (DASTUR, 2008, p. 21 E 22).

Além disso, a questão do ser é, a partir de então, reconhecida como partindo do modo de ser do homem finito e em uma condição prévia à toda determinação racional, como Dasein. É porque o Dasein possui uma compreensão de ser dos entes e de si mesmo, que ele é capaz de fundar a pergunta sobre o sentido do ser. De modo que, a questão do ser em Ser $e$ tempo não é assumida mediante uma generalidade abstrata, mas a partir do modo em que ela é capaz de afetar e concernir ao próprio interrogador (DASTUR, 2008, p. 22).

A abertura do Dasein à compreensão de ser só é possível sob a imposição e a antecipação de sua finitude, ou seja, porque ele é um-ser-para-a-morte. Sendo este um dos existenciais que o constituem. Com o termo ser-para-a-morte, Heidegger não pretende afirmar que as nossas possibilidades fáticas são concretizadas em função de nossa morte. O "para" da expressão "ser-para-a-morte" indica o modo como nós estamos sempre em "direção a" morte. Ela é a nossa mais extrema possibilidade, a possibilidade de nossa impossibilidade e, no momento em que acontece, deixamos de ser possibilidade de ser. Deixamos de ser-no-mundo e passamos a ter o modo de ser simplesmente dado.

A morte é então assumida como o alicerce da vida. E a vida, por sua vez, é apropriada não mais em uma oposição e resistência à morte. Ela passa a contar com ela como algo certo e incontornável. A sua grandiosidade está no modo de ser um nada, uma absoluta aniquilação. Não se pode imaginar nada além dela, nem eternidade, nem alma, nem Deus (DASTUR, 2008, p. 24).

Não obstante, precisamos alertar que a morte não é pensada por Heidegger como um limite negativo. Ela é pensada de um modo positivo como antecipação de nossas 
possibilidades de ser. Ou seja, para ele apenas somos capazes de nos apropriar de nossas possibilidades de ser porque somos um ser-para-a-morte. Do contrário, os projetos fáticos de nossa existência não seriam possíveis. Para auxiliar a nossa compreensão desse limite positivo da morte, Vallega compara a descrição desse existencial com o conceito grego de peras. Essa palavra aponta para um limite que libera algo dentro dele (VALLEGA, 2003, p. 13). Do mesmo modo, a morte do Dasein é um limite que libera a sua mais própria possibilidade (HEIDEGGER, 2008, p. 325 e 326). É por meio dela que o Dasein pode se diferenciar do mundo cotidiano e impessoal ao qual está lançado e assumir a sua singularidade, o seu ser mais próprio. Isso porque a morte é uma determinação intransponível, cada um a assume inevitavelmente como sua.

Desse modo, a descrição do existencial ser-para-a-morte não procura apresentar uma reflexão sobre a experiência da morte. Do contrário, Heidegger continuaria reivindicando um ponto de vista transcendente à própria condição finita do homem. Uma vez que não é possível a este fazer sua experiência, pois, quando ela acontece, ele deixa de ter compreensão de ser. Heidegger nos alerta que não é possível decidir sobre a possibilidade de um outro modo de ser ou um outro mundo, após a morte. É a "vida" que está sendo pensada em Ser e tempo com a descrição desse existencial (HEIDEGGER, 2008, p. 321 e 323). Ou seja, a essência da morte só pode ser determinada pela essência da vida (HEIDEGGER, 2008, p. 322).

Pensar a morte como extrema possibilidade do Dasein não significa apontá-la como um esgotamento de suas possibilidades. Ele não se completa, não chega ao seu acabamento 5 quando finda ${ }^{6}$. Enquanto possibilidade limite, a morte interrompe e retira todas as outras possibilidades, isto é, o seu caráter antecipativo de poder-ser. Como ela é a extrema possibilidade e com ela o Dasein perde o seu modo de ser-no-mundo, ela não pode ser contornada, nem superada. Por isso, Heidegger afirma que a morte é uma possibilidade própria, certa, irremissível, indeterminada e insuperável (HEIDEGGER, 2008, p. 335). Pois, o Dasein assume a "sua" morte no mesmo momento em que existe como um ser-no-mundo. Não lhe é possível transferi-la para outrem, nem assumir a morte do outro como sua. E embora não se saiba o momento em que acontecerá, a certeza de sua chegada é uma imposição ontológica à sua existência.

\footnotetext{
${ }^{5}$ Essa expressão aqui possui um sentido diferente daquele pensado no texto $A$ superação da metafisica. Nesse texto, essa expressão designa um modo de acontecimento e transformação epocal, referente à era da técnica. Em Ser e tempo, essa expressão está mais próxima do sentido usual de acabar, completar, terminar.

${ }^{6}$ Heidegger entende por "findar" a morte do Dasein. E diferencia essa expressão da palavra "finar", que designa a morte dos outros seres vivos que não possuem compreensão de ser.
} 
A fuga não é uma possibilidade de evitá-la, mas de esquecê-la em meio às nossas ocupações cotidianas. Nelas, sabe-se que a morte é um fato por ter notícias da morte dos outros. Morre-se, mas enquanto a morte não nos advém, ela não é encarada como uma ameaça. Contudo, o Dasein não pode livrar-se de assumir ao menos uma única vez o seu ser próprio, que é a certeza de sua finitude. Não lhe é possível transferir a sua morte a outrem, nem livrar o outro da morte. Pode-se até fazer sacrifícios e morrer em nome de alguém, mas essa morte já não é mais do outro e, em algum momento, o outro também se deparará com a sua própria morte. Desse modo, mesmo que no mundo impessoal o Dasein possa decidir pela fuga da possibilidade de assumir o seu ser próprio, a possibilidade extrema que lhe confere tal singularidade não pode ser eliminada. Por isso, a possibilidade de assumir essa singularidade perante o mundo da impessoalidade é chamada por Heidegger de "liberdade para a morte" (HEIDEGGER, 2008, p. 343). Pois, além da escolha por assumir a sua existência de um modo próprio, ela também é um reconhecimento da sua finitude e uma aceitação da angústia.

É na angústia que a morte se abre para o Dasein de um modo mais originário. A angústia é considerada uma disposição fundamental que retira o Dasein do mundo público, impessoal e familiar da decadência e o depara com a sua finitude e com o fato de estar fundado no nada. Ou seja, com o fato de que não há nenhum fundo que o sustente além das puras possibilidades de ser e que a sua possibilidade mais extrema é a morte. Desse modo, o fundo que sustenta o Dasein é o nada, porque ele lhe revela a possibilidade da impossibilidade de sua existência. Por ser um momento existencial no qual o Dasein se depara com uma suspensão de mundo, em que só lhe restam diante de si as suas possibilidades finitas de ser, a angústia abre ao Dasein a possibilidade e a responsabilidade de assumir o seu poder-ser de um modo próprio.

Perante as reflexões sobre o modo como Heidegger pensa a finitude do Dasein por meio do existencial ser-para-a-morte, almejamos questionar se com esse conceito também podemos considerar Ser e tempo como uma obra do fim da metafísica. E em que sentido. Discutiremos essa possibilidade a seguir, em diálogo com a defesa de John Sallis de que essa obra consuma uma realização do fim da metafísica. 
IV

Podemos considerar Ser e Tempo como uma proposta de realização do fim da metafísica?

Como vimos anteriormente, desde os seus escritos de juventude, Heidegger se propõe realizar um retorno à história da filosofia. Em Ser e tempo, esse retorno é levado a termo como uma proposta de destruição dos conceitos fundamentais da metafísica tradicional, a partir da qual seria possível perceber o modo como o conceito de ser foi escamoteado ao longo dessa história, obstruindo a possibilidade de questionar o seu sentido e oferecer, assim, uma abordagem adequada sobre as questões fundamentais da filosofia.

A partir da Kehre, entendida como uma virada no seu pensamento realizada entre 29 e a década de 30 , esse retorno passou a se configurar como uma crítica à metafísica como história do esquecimento do ser e como uma necessidade de recomeço. Doravante, esse recomeço passaria a levar em conta o modo como esse esquecimento determina a sua consumação. Com base nos desdobramentos das reflexões desse período e dos escritos chamados Contribuições à Filosofia, Heidegger percebe que a história da metafísica, ao adentrar na era da técnica, começa a caminhar para a consumação de seu fim. É chegado o momento em que a filosofia se converte em ciência e técnica. Diante desse acontecimento, Heidegger defende a necessidade de realizar um outro começo na história da filosofia. Um recomeço que desse conta de mostrar o modo como essa história se tece como errância e se consuma como esquecimento do ser.

Segundo John Sallis, esse acontecimento pode ser visto como uma (nova) tentativa de levar a termo as próprias possibilidades da filosofia, ou seja, do seu fim. E que, a despeito das diferenças do seu pensamento de juventude e de maturidade, já é possível encontrar em Ser e tempo tentativas de realizar esse fim, uma vez que a proposta de uma ontologia fundamental não é senão uma busca pela realização das possibilidades autênticas da filosofia. Dessa maneira, a história da filosofia é vista por ele como um conjunto de tentativas de transgressão de suas possibilidades, com vistas à realização de seu fim.

Pretendemos aqui problematizar a possibilidade de já considerar Ser e tempo uma obra que traz uma leitura sobre o fim da metafísica como realização e transgressão de suas possibilidades - ainda que essa obra anteceda as reflexões sobre a "era da técnica". Para isso, acompanharemos o argumento sustentado por J. Sallis ao defender essa possibilidade, e confrontaremos a sua tese, em um segundo momento, com os dois conceitos de finitude 
pensados por Heidegger, a saber: o de ser-para-a-morte, como parte da analítica do Dasein e o de acabamento da metafísica, realizado entre a década de 30 e 40.

Apesar de Ser e tempo ser uma obra que antecede a crítica do fenômeno do fim da metafísica, talvez seja possível afirmar que a preocupação de Heidegger de desobstruir e reconstituir a questão há muito tempo escamoteada pela história da filosofia possa ser explicada como uma tentativa de trazer a filosofia a sua própria realização. Essa é uma das defesas de John Sallis, no livro Delimitation: Phenomenology and the end of metaphysics. Contudo, é preciso que tenhamos cuidado com essa interpretação por alguns motivos:

O primeiro deles é que não há em Heidegger uma preocupação teleológica da história. De modo que não podemos atribuir a ele a concepção de que a história pudesse atingir a sua plena realização. Ao contrário, para ele, desde Ser e tempo, a história se perfaz a partir de algumas possibilidades de ser, e tais determinações não advêm de um processo necessário, causal e progressivo, mas de um projeto permitido pela coparticipação do homem (enquanto Dasein) e do mundo (enquanto mundanidade).

O segundo motivo é que a tentativa de reconstituir a história da metafísica a partir da destruição ainda não vislumbrava que a necessidade de recomeço advinha do fato de que a filosofia estava caminhando para seu fim, por estar se transformando em técnica. Nesse sentido, se considerarmos Ser e tempo como uma obra do fim da metafísica será unicamente pelo fato de haver para Heidegger uma necessidade de superação e um apelo ao reconhecimento da finitude do homem, da história, e consequentemente, dos fundamentos da metafísica. Tal finitude está sendo pensada através do modo de ser-para-a-morte do Dasein, mediante o qual ele mantém uma relação com as suas possibilidades de ser como antecipação. $\mathrm{Na}$ crítica ao período do acabamento da metafísica, ela é concebida, não mais como uma estrutura, mas em seu próprio acontecimento. Ou seja, no extremo limite da perda incontornável de um modo de ser para dar lugar a um outro - que não lhe é totalmente estranho, mas brota do seu próprio cerne, e é a sua própria radicalização. E esta distinção entre as duas reflexões sobre a finitude que Sallis não parece levar em conta.

Mas para se precaver desse tipo de dificuldade, Sallis indica a multiplicidade de sentidos que o termo "fim da metafísica" foi capaz de abarcar ao longo da história, e mostra como essa multiplicidade de sentidos não é alheia uma a outra, uma vez que estas concepções de fim brotam de tais determinações realizadas pela tradição metafísica (SALLIS, 1995, p 17). São quatro os significados de fim: 
O primeiro abordado por ele é o de Nietzsche. Ele é o filósofo que mais proclamou o fim da metafísica, com afirmações sobre a morte de Deus como o ser mais elevado e perfeito, a supressão do ser enquanto ser, ou ainda, sobre o modo como a verdade se tornou uma fábula, tal como afirmada em Crepúsculo dos ídolos (2005). Com a derrocada dessas noções, a metafísica alcança o sentido de fim como eliminação de suas possibilidades. $\mathrm{O}$ que não significa um desaparecimento efetivo da metafísica, pois, apesar da morte de Deus ter sido proclamada e, assim, as possibilidades da metafísica terem sido suprimidas, esta ainda continuaria a projetar a sua sombra no mundo. Fazendo um apelo para as renovações de sua própria possibilidade e não para novas determinações (SALLIS, 1995, 19).

O segundo sentido de fim trazido por ele foi traçado antes de Nietzsche e já se anunciava com Kant, na Crítica da razão pura, ao tentar corrigir a velha metafísica cartesiana, trazendo-a para suas possibilidades legítimas de realização. Hegel deu continuidade ao esforço kantiano na Fenomenologia do espírito, almejando trazer a filosofia ainda para mais perto da ciência. Nesse sentido, o fim da metafísica não poderia ser uma negação do que precedeu, mas a sua própria completude, ao realizar e trazer à perfeição aquele conhecimento que moveu toda a história da metafísica, em um processo de autoconhecimento e apropriação do espírito. O fim da metafísica seria assim uma realização do espírito absoluto.

Diante dessa multiplicidade de sentidos, restaria a questão de saber se uma ontologia fundamental poderia ser capaz de realizar uma possibilidade escamoteada ao longo de toda uma tradição - trazendo a filosofia às suas possibilidades autênticas, como proporia Ser $e$ tempo. E se essa leitura da ontologia fundamental como realização da questão originária que a tradição não fora capaz de resolver implicaria juntamente com o ensaio de retorno e recomeço da filosofia levado a termo como destruição, também em uma inclinação para o fim da filosofia. E se isso for possível, em qual sentido? Essa interpretação levaria a uma eliminação de todas as outras possibilidades da filosofia? Seria o fim da noção de historicidade, e consequentemente o fim da própria filosofia?

Sallis toma esse sentido hegeliano de realização para pensar a metafísica de Heidegger dentro desse fenômeno de acabamento. Contudo, esse acabamento não estaria mais sendo pensado nos termos de um acolhimento do passado em um processo de realização do espírito. Mas como uma tentativa de deslocamento da questão, para superar a esfera da metafísica acabada e, assim, transgredir os seus limites. 
Posteriormente, ele analisa o terceiro sentido de fim. Que é aquele pensado por Heidegger como o modo pelo qual a metafísica alcança as suas possibilidades mais extremas. Esta descrição condiz com período da história no qual estamos situados. E, segundo Sallis, a tarefa do pensamento contemporâneo deveria ser, a partir de Heidegger, superar esse acabamento, ao pensar possibilidades de transgredi-lo. E, embora ele não deixe claro, esse parece ser o quarto sentido de fim (como transgressão), o qual ele pretende seguir.

Sabemos que o empenho de Heidegger é o de tornar explícito o modo como a modernidade caminha para a realização do "fím da metafísica". Contudo, é preciso perceber que para ele tal fenômeno não possui o sentido de finalização, de término. Tampouco de realização de sua mais elevada perfeição, em um sentido hegeliano. Mas ao contrário, o fenômeno da metafísica acabada consuma um tipo de acolhimento radicalmente diferente: é o acontecimento no qual a história da filosofia é acolhida dentro de sua mais extrema possibilidade, na qual a metafísica se converte em ciência e técnica. Nesse sentido, fim ou acabamento da metafísica significa uma transformação das possibilidades da metafísica advindas da radicalização do projeto cartesiano de filosofia. Em O fim da filosofia e a tarefa do pensamento, Heidegger associa o antigo significado da palavra fim no alemão, Ende, ao sentido de lugar, Ort. O fim da metafísica passa assim a ser o lugar de reunião dessa possibilidade extrema (HEIDEGGER, 1979, p. 72).

Mas de onde provém a associação da descrição desse fenômeno com a analítica existencial presente em Ser e tempo? A análise do ser-para-a-morte mostra que a morte é a possibilidade limite da vida do Dasein, a sua extrema possibilidade. Um modo de ser insuperável e intransponível. Uma possibilidade que retira todas as outras e fecha a abertura para o futuro. O Dasein vive antecipadamente em direção a sua morte, como projeto de possibilidades finitas de ser. Nesse sentido, o ser-para-a-morte circunscreve a própria finitude do Dasein, e consequentemente, da história e da temporalidade. Para Sallis, o mesmo se dá com o fenômeno do acabamento da metafísica. Ele exaure todas as outras possibilidades e fecha toda abertura para o futuro. E enquanto permanecer intacta, ou seja, definida nos próprios termos, ela não pode ser superada.

Contudo, discordamos do Sallis sobre essa comparação entre os dois sentidos de fim. Se definirmos o acontecimento do 'fim da metafísica' pensada na Kehre nos mesmos termos da analítica existencial, a consequência seria a insuperabilidade da era da técnica. E não parece ser essa a proposta de Heidegger, e nem mesmo a defesa de Sallis ao refletir sobre a necessidade de transgredir tal fim. A filosofia de Heidegger é, desde seu início, marcada pela 
tentativa de superação da metafísica. O que só seria possível, se essa tentativa não fosse encarada como uma ruptura, uma saída da metafísica, pois é essa saída que conduz a realização de seu fim. A proposta de superação, ao contrário, se configura como um retorno a ela sob a forma de um recomeço que, seja no modo de destruição de seus conceitos fundamentais, seja como uma crítica dessa história como esquecimento do ser, pudesse apontar para a necessidade de reconhecer que nos consumamos como historicidade e destino de ser.

Não obstante, concordamos com Sallis quando afirma que já em Ser e tempo o retorno à história como destruição é uma tentativa de recomeço da filosofia. Mas acreditamos que é preciso ter cuidado ao afirmar que esse novo começo também representa o seu fím. Já que a proposta de descrever uma ontologia fundamental para questionar o sentido do ser não é senão uma tentativa de reconstituir as suas possibilidades, ao revelar o seu caráter de abertura para os seus modos históricos de ser. Interpretar tal recomeço no sentido teleológico de fim como Sallis propõe -, poderia dar margem a própria negação dessa abertura para a historicidade, e consequentemente para o futuro do pensamento.

Dessa maneira, entendemos que já há em Ser e tempo uma tentativa de engajamento no que Heidegger chamará na segunda fase de seu pensamento de destino da história da filosofia, de modo que há nele uma inclinação a uma autocompreensão de sua filosofia como parte deste acontecimento de ser. Embora essas intenções estejam presentes em Ser e tempo de um modo mais tímido e cuidadoso. Mas disso não podemos concluir que o conceito de finitude presente nesta obra possa ser pensado nos mesmos termos da sua crítica sobre o "fim da metafísica", apresentada a partir da segunda fase de sua filosofia.

Mas é possível, em alguma medida, aproximar a descrição do "ser-para-a-morte" com a crítica do "fim da metafísica"?

Sabemos que a crítica realizada em Ser e tempo não está voltada para a era da técnica, mas para o projeto inicial da modernidade. Desse modo, ela não pode ser pensada como uma crítica ao fim da metafísica, se descrita nos mesmos termos da segunda fase de seu pensamento. Da mesma maneira, após a Kehre, Heidegger deixa de descrever o modo de ser do Dasein a partir de sua constituição existencial e, gradativamente, deixa de usar o termo Dasein para designar o modo de ser do homem. Consequentemente, o fenômeno do ser-paraa-morte não encontra lugar na crítica à era da técnica, se pensado nos mesmos termos.

O que, então, há em comum entre essas duas abordagens? Podemos apontar o modo de pensar o dar-se do ser a partir de uma historicidade. E é por essa via, que Heidegger realiza e 
aprofunda a sua crítica à decisão da história da metafísica, de Platão a Nietzsche, de tomar o ente pelo ser. De modo que, não há uma ruptura entre a crítica ao projeto inicial da modernidade realizada em Ser e tempo e a crítica à era da técnica como traço essencial da modernidade tardia. Mas há, ao contrário, uma continuidade e um aprofundamento da primeira abordagem. Com a historicidade como modo de essencialização do ser, as determinações fundamentais da metafísica passam a ser pensadas em sua finitude. Assim, podemos afirmar que Heidegger mantém a finitude como condição para a historicidade em ambas as fases. Mas na era da técnica, momento no qual vivemos o fim da metafísica, o homem não é capaz de se dar conta que ele e sua história são condicionados por uma finitude. $\mathrm{O}$ acontecimento do fim tem o seu lugar justamente no fato de ainda não sermos capazes de reconhecer o limite de nossa era e a possibilidade de superá-la. Pois, o domínio desta tem a aparência de uma incondicionalidade. Contudo, não podemos esquecer que a sua superação depende muito mais de uma abertura, do que propriamente da vontade humana. De modo que, reconhecer as insuficiências desse período acaba não sendo o mesmo que superá-las. Pois, tal possibilidade depende de uma disposição epocal.

O que marca a diferença entre ambas as concepções de fim é que o conceito de fim ou acabamento como extrema possibilidade da metafísica é um modo de esquecimento do ser e, mais do que isso, o mais extremo, o esquecimento do esquecimento. O ser-para-a-morte designa, ao contrário, um caráter de abertura do Dasein, e assim não pode ser tomado como um modo de esquecimento, ou, fechamento do ser. Embora ele também possua essa determinação ontológica, por estar lançado na decadência. Mas tal fechamento de ser deriva do caráter de abertura de nossa existencialidade. Além disso, o nosso modo de ser-para-amorte não pode ser superado, e nem tratado como uma dificuldade epocal. Ele é a condição para que qualquer proposta de superação de dificuldades históricas seja possível. De modo que, essa determinação ontológica não pode ser superada, mas é uma condição para a superação das possibilidades de ser.

\section{Considerações finais}

Perante o que foi escrito é importante ressaltar que esses conceitos de finitude, seja o pensado a partir da descrição do ser-para-a-morte, seja aquele que se expressa na crítica ao acabamento da metafísica, não abarcam um sentido de finalização, término quer seja do homem, quer seja da história. Como dissemos anteriormente, a morte está sendo pensada 
como um alicerce, como parte da essência da vida. E assim, a existencialidade do ser-para-amorte se perfaz como antecipação de possibilidades de ser. E, no limite, como antecipação de sua extrema possibilidade, que é a própria morte. Contudo, essa possibilidade, tão certa quanto indeterminada, só pode ser pensada como e mediante esse caráter antecipativo. A tentativa de transpor essa condição conduziria a proposta de Ser e tempo a uma recaída numa narrativa do absoluto. Do mesmo modo, a finitude pensada a partir da Kehre diz respeito ao destino do ser, que confere mobilidade e a possibilidade de ultrapassamento de fundamentos epocais. O que permitiu à história da metafísica distintas determinações de fundamentos para a totalidade do ente. A constatação do "fim" ou "acabamento" da metafísica com a chegada da era da técnica, não presume uma aniquilação da metafísica, da filosofia ou da história, mas uma transformação advinda da exacerbação de suas possibilidades. Qual seja? A conversão da filosofia em ciência e técnica.

Diante dessa discussão, percebemos que apesar de não haver ruptura entre Ser e tempo e os escritos desenvolvidos a partir da Kehre, não podemos tomar os conceitos aqui em jogo como equivalentes, simplesmente por almejarem uma crítica à mesma tradição metafísica. Se isso fosse possível, essa obra não haveria sido deixada inacabada.

Entendemos que não foi fortuita tal decisão de deixar a obra Ser e tempo inacabada e deslocar a questão do ser para um novo ponto de partida, levado a termo na Kerhe. Havia uma necessidade de sair da perspectiva e do privilégio do Dasein e dos pressupostos de uma abordagem transcendental que tal abordagem carregava consigo. Não obstante, essa virada não foi estabelecida como uma ruptura, mas ao contrário, como modo de repensar a questão do ser de uma maneira mais originária e profunda. Assim, ao longo de toda a filosofia de Heidegger nos deparamos com o seu empenho de encontrar um modo mais apropriado e profundo para refletir sobre a mesma questão: como é possível trazer à luz o modo como a questão do ser se constituiu (e se constitui) como fio condutor de nossas determinações históricas? Essa questão foi assumindo novas formas de abordagem, na tentativa de se desarraigar dos pressupostos da tradição metafísica. Bem como deparou-se com uma outra dificuldade oriunda da radicalização de determinações dessa tradição. Qual seja? O acontecimento do fim da metafísica.

Quando Heidegger apresentou Ser e tempo como uma tentativa de, por meio de uma destruição, reconduzir a filosofia à sua questão originária, escamoteada desde o início da história da metafísica, ele não encarou essa proposta como uma necessidade de trazer a metafísica à sua plena realização, ao seu fim, como supõe a leitura de Sallis. Tampouco, como 
uma necessidade de levar as determinações da filosofia moderna até as suas últimas consequências, tal como acontece a partir do advento da era da técnica. Mas, ao contrário, como uma necessidade de desobstruir os caminhos da filosofia e revelar o seu caráter de "possibilidade de ser". Explicitando assim o seu caráter de abertura para novas determinações, bem como a impossibilidade de oferecer um fundamento último para determinações oriundas de uma historicidade. Desse modo, entendemos que é possível encontrar em Ser e tempo uma inclinação a propor um "outro começo" para a história da filosofia, levada a termo como e a partir de uma superação da metafísica. Mas essa tentativa não pode ser associada a uma "realização do fim da metafísica". Uma vez que o conceito de finitude pensado a partir do existencial do ser-para-a-morte não se configura nem como uma finalização, nem como uma realização plena das possibilidades do Dasein e da filosofia. Mas como uma abertura antecipativa do Dasein para as suas possibilidades finitas de ser.

\section{REFERÊNCIAS BIBLIOGRÁFICAS}

DASTUR, F. La muerte: Ensayo sobre la finitude. Barcelona: Herder, 2008.

HAAR, M. Heidegger e a essência do homem. Lisboa: Piaget, 1990.

HEIDEGGER, M. Contribuições à filosofia: Acontecimento apropriador. Rio de Janeito: Viavérita, 2015.

Ser e tempo. Petrópolis: Vozes, 2008.

2010.

. A superação da metafísica. In: Ensaios e conferências. Petrópolis: Vozes,

A questão da técnica. In: Ensaios e conferências.: Petrópolis: Vozes, 2010.

Cartas sobre o humanismo. In: Conferências e escritos filosóficos. São Paulo: Abril Cultural, 1979. (Os pensadores).

O fim da filosofia e a tarefa do pensamento. In: Conferências e escritos filosóficos. São Paulo: Abril cultural, 1979.

Introdução à filosofia. São Paulo: Martins Fontes, 2008.

HUSSERL, E. Investigações lógicas. Lisboa: Centro de Filosofia da Universidade de Lisboa, 2007.

KANT, I. Crítica da razão pura. Lisboa: Calouste Gulbenkian, 2001.

HEGEL, F. Fenomenologia do espírito. Petrópolis: Vozes, 2011.

NIETZSCHE, F. A vontade de poder. Rio de Janeiro: Contraponto, 2008. . Assim falou Zaratustra. São Paulo: Companhia das letras, 2011. .A gaia ciência. São Paulo: Companhia das letras, 2016. .Crepúsculo dos ídolos. São Paulo: Companhia das letras, 2005.

SALLIS, J. Delimitations: Phenomonology and the end of metaphysics. Bloomington: Indiana University Press, 1995. 
VALLEGA-NEU, D. Heidegger's Contributions to philosophy: An introduction. Bloomington: Indiana University Press, 2003.

VATTIMO, G. O fim da modernidade. São Paulo: Martins Fontes, 2007. 